\title{
DETERMINAN EFEKTIVITAS PENGELOLAAN KEUANGAN BADAN LAYANAN UMUM DAERAH (BLUD): DIMODERASI SISTEM PENGENDALIAN INTERN PEMERINTAH
}

\author{
Mita Sandria ${ }^{1}$, Restu Agusti ${ }^{2 *}$, Adhitya Agri Putra ${ }^{3}$ \\ ${ }^{123}$ Program Studi Akuntansi, Fakulutas' Ekonomi dan Bisnis, Universitas Riau, Pekanbaru \\ *Email: restuagus@yahoo.com
}

\begin{tabular}{l}
\hline Keywords \\
\hline Information Technology, \\
Human Resources, \\
Functional Oversight, \\
Regional Public Service \\
Agency \\
\hline
\end{tabular}

\section{Article Information}

Received:

2020-04-21

Accepted:

2020-07-05

Available online:

2020-07-18

\begin{abstract}
This study aims to determine the effect of the use of information technology, human resource competency, and functional oversight of the effectiveness of financial management of local public service agencies with the government's internal control system as a moderating variable. The data used in this study are primary data with questionnaires as instruments. The number of samples in this study were 112. However, only 92 (82,14\%) respondents returned the questionnaire and could be processed. Data in this study were analyzed using the Structural Equation Modeling (SEM) model. Testing the hypothesis in this study using a significance level of 5\% (0.05). The results of this study indicate that the use of information technology, human resource competencies, and functional oversight effect on the effectiveness of financial management of regional public service bodies and internal control systems can moderate the relationship of the use of information technology, human resource competencies, and functional oversight of the effectiveness of financial management bodies regional public services.
\end{abstract}

\section{PENDAHULUAN}

Undang-undang Nomor 1 Tahun 2004 tentang Perbendaharaan Negara merupakan salah satu undang-undang yang dibentuk dalam rangka reformasi keuangan negara yang dilakukan oleh pemerintah indonesia. Pasal 68 dan 69 undang-undang tersebut menyebutkan tentang pengelolaan keuangan Badan Layanan Umum (BLU). BLU dibentuk untuk meningkatkan pelayanan kepada masyarakat dalam rangka memajukan kesejahteraan umum dan mencerdaskan kehidupan bangsa. BLU merupakan bagian dari pemerintah pusat sedangkan Badan Layanan Umum Daerah (BLUD) merupakan bagian dari pemerintah daerah. 

Oleh karena itu, baik BLU maupun BLUD merupakan salah satu kebijakan pemerintah dibidang keuangan negara untuk meningkatkan pelayanan pada masyarakat.

Menurut PP Nomor 12 Tahun 2019 tentang Pengelolaan Keuangan Daerah, Badan Layanan Umum Daerah yang selanjutnya disingkat BLUD adalah sistem yang diterapkan oleh unit pelaksanaan teknis dinas/badan daerah dalam memberikan pelayanan kepada masyarakat yang mempunyai fleksibiltas dalam pola pengelolaan keuangan sebagai pengecualian dari ketentuan pengelolaan daerah pada umumnya. Di dalam pengelolaan keuangan daerah Badan Layanan Umum Daerah (BLUD) melakukan pengelolaan keuangan nya sendiri, seperti rumah sakit atau unit kerja pada organisasi perangkat daerah seperti Puskesmas di lingkungan pemerintah daerah yang dibentuk untuk memberikan pelayanan kepada masyarakat berupa penyediaan barang dan/atau jasa yang dijual tanpa mengutamakan mencari keuntungan, dalam melakukan pelayanan (PP Nomor 23 Tahun 2005).

Perubahan yang dinamis dan cepat dalam era birokrasi membawa dampak besar bagi dunia kesehatan khususnya Puskesmas sebagai tempat layanan kesehatan pertama bagi masyarakat pada setiap lingkupan daerah. Puskesmas dituntut dapat mengelola keuangannya agar lebih efektif dan digunakan dengan tepat sasaran, serta memberikan pelayanan kesehatan kepada masyarakat dengan kinerja terbaik dari tenaga kesehatan, memberi pelayanan kesehatan kepada masyarakat memiliki peran sangat penting dalam meningkatkan derajat kesehatan masyarakat.

Menurut Mardiasmo (2009) efektivitas merupakan ukuran berhasil atau tidaknya suatu organisasi mencapai tujuannya. Suatu organisasi dikatakan berhasil apabila telah mencapai tujuannya dan berjalan efektif. Efektivitas dalam pengelolaan keuangan daerah merupakan penyelesaian seluruh kegiatan meliputi perencanaan dan penganggaran, pelaksanaan anggaran, pelaporan dan pertanggungjawaban serta pengawasan tepat pada waktunya dan di dalam batas anggaran yang telah tersedia, dan tercapainya tujuan atas sasaran yang telah direncanakan (Halim, 2004).

Namun pada kenyataannya, pengelolaan keuangan BLUD masih belum dapat dikatakan efektif. Fenomena yang terjadi saat ini dari hasil evaluasi Dinas Kesehatan Kabupaten Pelalawan di penghujung tahun 2018, masih ada 4 Puskesmas yang berada di Kabupaten Pelalawan realisasi anggarannya belum mencapai target yang telah ditentukan dan realisasinya rata-rata masih sebesar 55-64\%.

Hal yang sama juga terjadi di Puskesmas Kota Pekanbaru tahun 2017 yaitu Puskesmas Kota Pekanbaru yang telah berstatus BLUD telah diberikan anggaran untuk peningkatan pelayanan kesehatan masyarakat sebesar 38.310.855.938 dengan target yang telah ditentukan 
yakni 100\%. Namun, realisasi atas anggaran tersebut hanya 22.911.328.049 atau sebesar 59,80\%. Jumlah tersebut menunjukkan Puskesmas di pekanbaru belum mampu merealisasikan perencanaan anggaran yang telah ditetapkan (LAKIP Dinas Kesehatan Kota Pekanbaru, 2018).

Penelitian terdahulu telah mengkaji mengenai efektivitas pengelolaan Badan Layanan Umum (misalnya Priastuti, 2017; Ashari, 2019); Lidyawati, 2019). Namun penelitian mereka lebih memfokuskan pada efektivitas anggaran dan penilaian kinerja. Beberapa penelitian terdahulu yang mengkaji penyebab efektivitas pengelolaan Badan Layanan Umum menemukan belum efektifnya pengelolaan keuangan BLUD dapat disebabkan oleh berbagai hal. Contohnya seperti pemanfaatan teknologi informasi (Ahmad, 2015; Arfianti, 2011), SDM (Nurjannah, 2014; Iskandar, 2015; Tanzerina, 2015; Utami,. 2016; Sari et al, 2017), pengawasan (Iskandar, 2015; Lisdiani, 2015; Utami, 2016 ), SPIP (Nurjannah, 2014; Iskandar, 2015; Utami, 2016; Sari et al, ;2017 )

Pada penelitian ini, peneliti memfokuskan pada Puskesmas BLUD Puskesmas yang ada di Kabupaten Siak dan Kabupaten Pelalawan. Puskesmas merupakan tulang punggung penyelenggaraan upaya pelayanan kesehatan dasar bagi masyarakat di wilayah kerjanya. Sehingga penting rasanya Puskesmas untuk melakukan pengelolaan keuangan secara efektif untuk kepentingan masyarakat bersama.

Untuk menghasilkan laporan keuangan daerah yang baik agar pengelolaan keuangan efektif dibutuhkan teknologi yang baik untuk memudahkan dalam memproses data dan lain sebagainya. Pemberdayaan teknologi informasi tidak akan lepas dari pemanfaatan teknologi informasi secara optimal dan akan membawa manfaat bila ada kemauan dan kemampuan untuk mengoperasikan sesuai dengan kebutuhan, contohnya dalam penggunaan proses mengelola keuangan. Ahmad (2015) menyatakan bahwa variabel pemanfaatan teknologi informasi berpengaruh terhadap efektivitas pengelolaan keuangan daerah.

Dalam pencapaian efektivitas pengelolaan keuangan, tidak hanya dengan pemanfaatan teknologi informasi secara optimal tetapi pemerintah harus memiliki sumber daya manusia yang memahami dan berkompeten dalam akuntansi pemerintahan. Saleba (2014) menyatakan bahwa sumber daya manusia yang berkompeten akan mampu meningkatkan efektivitas pengelolaan keuangan daerah. SDM yang disiplin, professional dan berkualitas tinggi serta produktif akan menghasilkan efektivitas pengelolaan keuangan BLUD. Begitu pula sebaliknya apabila sumber daya tidak berkompeten maka dalam pencapaian efektivitas pengelolaan keuangan daerah tidak tercapai. 
Efektifitas pengelolaan keuangan daerah juga harus didukung oleh fungsi pengawasan. Dengan adanya pengawasan fungsional dapat diketahui apakah suatu instansi pemerintah telah melaksanakan kegiatan sesuai dengan tugas dan fungsinya secara efektif dan efisien, serta sesuai dengan rencana, kebijakan yang telah ditetapkan. Berdasarkan penelitian yang dilakukan oleh Utami (2016) bahwa Pengawasan Fungsional berpengaruh signifikan terhadap Efektivitas Pengelolaan Keuangan Daerah pada SKPD Kabupaten Lima Puluh Kota Payakumbuh Sumatra Barat. Hal ini menunjukkan bahwa semakin tinggi Pengawasan Fungsional yang dimiliki aparat Pemda dalam menjalankan penugasan prefesionalnya, maka akan semakin tinggi pula efektivitas pengelolaan keuangan daerah yang dihasilkan.

Dalam efektivitas pengelolaan keuangan selain pemanfaatan teknologi informasi, kompetensi sumber daya manusia dan pengawasan fungsional ternyata ada hal yang lain dapat memperkuat atau memperlemah setiap variabel. Sistem pengendalian intern merupakan salah satu unsur penting dalam pengelolaan keuangan suatu organisasi sektor publik. Lembaga pemerintah sebaiknya memiliki suatu sistem pengendalian agar dapat meminimalkan risiko yang ada. Pengendalian internal dalam pemerintahan sangat diperlukan untuk menghindari tindakan-tindakan kecurangan yang mungkin ataupun telah dilakukan oleh berbagai pihak yang berkecimpung di dunia pemerintahan. Walaupun aktivitas dalam pengelolaan keuangan bagus namun pengedalian internal pemerintah lemah maka dapat memperlemah aktivitas untuk mencapai efektivitas. Jika aktivitas dalam pengelolaan keuangan daerah diiringi dengan pengawasa internal pemerintah yang baik maka akan semakin mencapai efektivitas dalam pengelolaan keuangan daerah.

Dalam suatu organisasi pemerintahan terdapat suatu sitem pengendalian intern pemerintah yang dapat mempengaruhi secara kuat atau lemah efektivitas pengelolaan keuangan yang ada di dalam organisasi pemerintah. Hal ini sesuai dengan penelitian Sinambow et al (2017) yang menyatakan dan menunjukkan bahwa sistem pengendalian intern pemerintah berpengaruh dan memperkuat efektivitas pengelolaan keuangan daerah.

Berdasarkan uraian di atas penulis tertarik untuk mengkaji efektivitas pengelolaan keuangan daerah. Penelitian ini memfokuskan pada instansi layanan kesehatan yaitu Puskesmas yang telah memiliki status sebagai Badan Layanan Umum Daerah. Penelitian terdahulu sebagian besar dilakukan pada organisasi pemerintahan dan masih sedikit yang melakukan kajian pada sektor kesehatan Puskesmas. Oleh sebab itu penelitian menarik untuk dilakukan karena penelitian pada organisasi pemerintahan tidak dapat digeneralisasi pada organisasi kesehatan.

Penelitian ini juga menggunakan variabel Pemanfaatan Teknologi Informasi dan 
Kompetensi Sumber Daya Manusia yang tidak digunakan pada penelitian sebelumnya (Lisdiani ,2015). Hal ini didasarkan pada hasil penelitian sebelumnya, dua variabel ini masih memiliki hasil yang belum konsisten terhadap efektivitas pengelolaan keuangan. Selain itu penelitian ini juga menggunakan variabel moderasi yaitu Sistem Pengendalian Intern Pemerintah (SPIP) untuk menjelaskan hubungan antara pemanfaatan teknologi informasi, kompetensi sumber daya manusia dan pengawasan fungsional terhadap efektivitas pengelolaan Puskesmas BLUD. Merujuk pada Permedagri No. 13 Tahun 2006 tentang Pedoman Pengelolaan Keuangan Daerah yang menyatakan bahwa Sistem Pengendalian Intern Pemerintah merupakan proses yang dirancang untuk memberikan keyakinan yang memadai mengenai pencapaian tujuan pemerintah daerah sehingga dapat menciptakan efektivitas dan efisiensi pengelolaan keuangan pemerintah. Hal ini juga didukung oleh penelitian Tanzerina (2016) yang menunjukkan SPIP berpengaruh dan dapat memperkuat efektivitas pengelolaan keuangan daerah. Berdasarkan latar belakang dan fenomena yang ada di atas, peneliti ini bertujuan untuk menguji pengaruh pemanfaatan teknologi informasi, kompetensi sumber daya manusia dan pengawasan fungsional sebagai faktor yang menentukan efektifitas pengelolaan keuangan BLUD serta menguji moderasi sistem pengendalian intern pada hubungan pemanfaatan teknologi informasi, kompetensi sumber daya manusia dan pengawasan fungsional dengan efektivitas pengelolaan BLUD.

\section{PENGEMBANGAN HIPOTESIS}

\section{Pengaruh Pemanfaatan Teknologi Informasi Terhadap Efektivitas Pengelolaan Keuangan}

\section{Badan Layanan Umum Daerah (BLUD)}

Pemanfaatan teknologi informasi secara optimal, digunakan oleh aparatur pemerintah dalam mempengaruhi kualitas pelaporan keuangan yang mengandung unsur relevan, andal, dapat dibandingkan dan dapat dipahami oleh para penggunanya. Pemanfaatan teknologi yang tepat dan didukung oleh keahlian personil yang mengoperasikannya dapat meningkatkan kinerja perusahaan maupun kinerja individu yang bersangkutan. Pemanfaatan teknologi informasi dapat menghasilkan laporan keuangan dengan cepat dan akurat sehingga laporan keuangan lebih efektif digunakan untuk pengambilan keputusan.

Dengan memanfaatkan teknologi informasi baik individu maupun organisasi dalam menjalankan berbagai aktivitas dengan lebih efektif dan efisien. Teknologi juga sebagai alat bantu pemerintah yang digunakan untuk meningkatkan efektivitas impelementasi dari berbagai regulasi bidang pengelolaan keuangan daerah seperti dalam perencanaan dan penganggaran, dll yang berdasarkan pada asas efisiensi, ekonomis, efektif, transparan, 
akuntabel, dan auditabel sehingga dapat meningkatkan efektivitas pengelolaan keuangan Badan Layanan Umum Daerah (djkd.kemendagri.go.id).

Hasil penelitian Ismanto (2010); Sukarta et al (2017) menyatakan bahwa pemanfaatan teknologi informasi memiliki peran yang strategi dan signifikan dan begitu juga pada penelitian Ahmad (2015) yang hasil penelitiannya bahwa variabel pemanfaatan teknologi informasi berpengaruh terhadap efektivitas pengelolaan keuangan daerah. Berdasarkan uraian di atas maka dapat dirumuskan hipotesis sebagai berikut:

\section{$\mathrm{H}_{1}$ : Pemanfaatan Teknologi Informasi berpengaruh Terhadap Efektivitas Pengelolaan Keuangan Badan Layanan Umum Daerah (BLUD).}

\section{Pengaruh Kompetensi Sumber Daya Manusia Terhadap Efektivitas Pengelolaan Keuangan BLUD}

Dalam pencapaian efektivitas pengelolaan keuangan, pemerintah harus memiliki sumber daya manusia yang berkompeten. Sehingga dapat dikatakan bahwa semakin tinggi kompetensi sumber daya manusia maka kemungkinan akan terjadi peningkatan efektivitas pengelolaan keuangan. Sebaliknya jika kompetensi sumber daya manusia turun, maka efektivitas pengelolaan keuangan akan turun. Hal ini didasarkan pada pemikiran sumber daya manusia merupakan satu asset yang berpengaruh terhadap efektivitas pengelolaan keuangan. Kompetensi sumber daya manusia adalah salah satu faktor yang menentukan keberhasilan suatu instansi. Dengan adanya komptenesi sumber daya manusia yang berkualitas, tentunya akan mampu mengelola keuangan dengan baik.

Saleba (2014) menyatakan bahwa sumber daya manusia yang berkompeten akan mampu meningkatkan efektivitas pengelolaan keuangan daerah, begitu pula sebaliknya apabila sumber daya tidak berkompeten maka dalam pencapaian efektivitas pengelolaan keuangan daerah tidak tercapai. Hal ini didukung oleh pengetahuan, perilaku, dan kemampuan individu dalam melaksanakan tugas. Nurjannah (2014); Amerieska (2016) menyimpulkan bahwa kompetensi sumber daya manusia berpengaruh terhadap efektivitas pengelolaan keuangan daerah. Berdasarkan uraian diatas maka dapat dirumuskan hipotesis sebagai berikut :

\section{$\mathrm{H}_{2}$ : Kompetensi Sumber Daya Manusia berpengaruh Terhadap Efektivitas Pengelolaan Keuangan Badan Layanan Umum Daerah (BLUD).}




\section{Pengaruh Pengawasan Fungsional terhadap Efektivitas Pengelolaan Keuangan Badan}

\section{Layanan Umum Daerah (BLUD)}

Halim (2004:312) menyatakan bahwa dalam pelaksanaan pengelolaan keuangan daerah, pengawasan fungsional mutlak dilaksanakan sehingga keefektifan, keefisien dan keekonomisan yang dilaksanakan oleh Pemerintah daerah dapat dicapai. Apabila pengawasan fungsional dilakukan oleh aparat pengawas fungsional dengan maksimal, maka efektivitas pengelolaan keuangan daerah akan tercapai. Terwujudnya pengelolaan keuangan yang efektif merupakan tujuan utama pemerintah daerah. Sehingga dengan dilaksanakannya pengawasan fungsional yang memadai akan menunjang pengelolaan keuangan yang efektif, efisien dan ekonomis.

Semakin baik pengawasan fungsional yang dilakukan oleh aparat pengawas fungsional maka pelaksanaan program kerja pemerintah akan semakin baik, hal ini akan mempengaruhi kefektivitasan dalam pengelolaan keuangan daerah. Pengawasan fungsional dapat meningkatkan adanya keefektivitasan pengelolaan keuangan daerah. Semakin sering melakukan pengawasan, maka semakin bagus pula efektivitas pengelolaan keuangan daerahnya.

Penelitian yang dilakukan oleh Utami (2016) bahwa Pengawasan Fungsional berpengaruh signifikan terhadap Efektivitas Pengelolaan Keuangan Daerah Hal ini juga sejalan dengan penelitian yang dilakukan oleh Iskandar (2015) bahwa pengawasan fungsional berpengaruh terhadap efektivitas pengelolaan keuangan daerah. Berdasarkan uraian diatas maka dapat dirumuskan hipotesis sebagai berikut:

$\mathrm{H}_{3}$ : Pengawasan Fungsional berpengaruh Terhadap Efektivitas Pengelolaan Keuangan Badan Layanan Umum Daerah (BLUD).

Pengaruh Pemanfaatan Teknologi Informasi, Kompetensi Sumber Daya Manusia, dan Pengawasan Fungsional Manusia Terhadap Efektivitas Pengelolaan Keuangan Badan Layanan Umum Daerah (BLUD) Dengan Sistem Pengendalian Intern Pemerintah (SPIP) Sebagai Variabel Moderasi

Untuk menghasilkan laporan keuangan daerah yang baik agar pengelolaan keuangan efektif dibutuhkan teknologi yang baik untuk memudahkan dalam memproses data dan lain sebagainya. Dalam pengelolaan keuangan daerah masing-masing lembaga pemerintah harus memiliki sistem pengendalian intern agar dapat meminimalkan risiko yang ada. Jika pengendalian internal tersebut berjalan dengan efektif dan efisien, pelaporan keuangan yang dihasilkan andal, aset milik negera tetap aman dan peraturan perundang-undangan dijalankan 
maka akan tercipta tata kelola pemerintahan yang baik. Dengan kata lain sistem pengendalian intern akan turut meningkatkan efektivitas pengelolaan keuangan daerah.

Dengan adanya sistem pengendalian intern pemerintah dapat mempengaruhi tata cara mereka bekerja dimana sistem pengendalian intern pemerintah dapat memoderasi hubungan pemanfaatan teknologi informasi terhadap efektivitas pengelolaan keuangan. Apabila sistem pengendalian intern di organisasi baik maka pegawai akan melakukan tugasnya dengan memanfaatkan teknologi informasi yang ada dengan sistem yang telah diterapkan oleh organisasi tersebut. Sebaliknya, apabila sistem pengendalian intern pemerintah yang ada di dalam organisasi tersebut tidak berjalan dengan baik maka akan memperlemah hubungan antara pemanfaatan terknologi informasi terhadap efektivitas pengelolaan keuangan. Dengan kata lain sistem pengendalian intern ini dapat memoderasi pengaruh pemanfaatan teknologi informasi terhadap efektivitas pengelolaan keuangan. Berdasarkan penelitian yang telah dillakukan sebelumnya oleh Tanzerina (2017) bahwa sistem pengendalian intern pemerintah dapat memoderasi pengaruh variabel independen terhadap efektivitas pengelolaan keuangan daerah.

Dalam penelitian ini sistem pengendalian intern pemerintah sebagai variabel moderasi dapat memperkuat dan memperlemah hubungan antara kompetensi sumber daya manusia dengan efektivitas pengelolaan keuangan, apabila kompetensi sumber daya manusia tinggi maka efektivitas pengelolaan keuangan semakin baik sebaliknya kompetensi sumber daya manusia yang buruk mengakibatkan efektivitas pengelolaan juga akan buruk. Namun apabila ditambahkan sistem pengendalian intern pemerintah maka hubungan antara kompetensi sumber daya manusia dengan efektivitas pengelolaan keuangan daerah dapat lebih kuat atau lebih lemah. Sistem pengendalian intern pemerintah dapat memperkuat dan memperlemah hubungan antara kompetensi sumber daya manusia dengan efektivitas pengelolaan keuangan. Apabila kompetensi sumber daya manusia tinggi maka efektivitas pengelolaan keuangan semakin baik, sebaliknya kompetensi sumber daya manusia yang buruk mengakibatkan efektivitas pengelolaan juga akan buruk.

Sistem pengendalian intern pemerintah bisa memperkuat atau memperlemah hubungan antara pengawasan fungsional dengan efektivitas pengelolaan keuangan. karena sistem pengendalian intern pemerintah akan menjadi tolak ukur dalam efektivitas pengelolaan keuangan sehingga pengelolaan keuangan akan efektif. Untuk pengawasan fungsional dilakukan, agar terarah pengelolaan keuangannya sesuai kebutuhan sehingga efektivitas pun tercapai. Apabila pengawasan fungsional dilakukan dan mengacu pada sistem pengendalian intern pemerintahan maka semakin baik pula pencapaian efektivitas pengelolaan keuangannya. 
Sebaliknya, apabila sistem pengendalian intern pemerintah yang ada tidak berjalan dengan semestinya maka akan pengelolaan keuangan yang ada menjadi tidak efektif. Berdasarkan penelitian yang telah dillakukan sebelumnya oleh Tanzerina (2017) bahwa sistem pengendalian intern pemerintah dapat memoderasi pengaruh variabel independen terhadap efektivitas pengelolaan keuangan daerah. Berdasarkan pemaparan di atas maka dapat di rumuskan hipotesis sebagai berikut:

\section{H4 $_{4}$ Sistem Pengendalian Intern Pemerintah Memoderasi Pengaruh Pemanfaatan} Teknologi Informasi terhadap Efektivitas Pengelolaan Keuangan Badan Layanan Umum Daerah (BLUD)

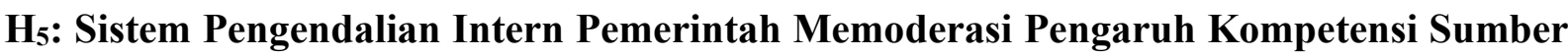
Daya Manusia terhadap Efektivitas Pengelolaan Keuangan Badan Layanan Umum Daerah (BLUD)

\section{H6: Sistem Pengendalian Intern Pemerintah Memoderasi Pengaruh Pengawasan Fungsional terhadap Efektivitas Pengelolaan Keuangan Badan Layanan Umum Daerah (BLUD)}

\section{METODE PENELITIAN}

\section{Lokasi dan Waktu Penelitian}

Penelitian ini dilakukan di lingkungan Kabupaten Siak dan Kabupaten Pelalawan yaitu pada Badan Layanan Umum Daerah Daerah (BLUD) Puskesmas di Kabupaten Siak dan Kabupaten Pelalawan pada tahun 2020, yang merupakan instansi pemerintah yang menyelenggarakan pelayanan kepada masyarakat.

\section{Populasi dan Sampel}

Populasi yang digunakan dalam penelitian ini adalah 28 Puskesmas yang ada di 2 kabupaten diantaranya 15 Puskesmas di Kabupaten Siak dan 13 Puskesmas di Kabupaten Pelalawan. Seluruh Puskesmas dijadikan objek penelitian. Responden dalam penelitian dipilih dengan kriteria pemilihan sampel yang ditetapkan adalah: 1) Kepala Puskesmas, 2) Kepala TU, 3) Bendahara Penerimaan, 4) Bendahara Pengeluaran dengan jumlah 112 sampel.

\section{Jenis dan Sumber Data}

Jenis data yang digunakan dalam penelitian ini adalah data primer. Sumber data dalam penelitian ini adalah pengumpulan data primer dalam penelitian ini melalui cara menyebarkan kuesioner secara langsung dengan pihak yang berhubungan dengan penelitian yang dilakukan. 
Sumber data dalam penelitian ini berupa kusioner yang disebar kepada Kepala Puskesmas, Kepala TU, Bendahara Penerimaan dan Bendahara Pengeluaran di seluruh Puskesmas yang berada di Kabupaten Siak dan Kabupaten Pelalawan.

\section{Teknik Pengumpulan Data}

Teknik pengumpulan data dalam penelitian ini yaitu dengan menggunakan kuesioner. Kuesioner pada penelitian ini ditujukan kepada Kepala Puskesmas, Kepala Tata Usaha, Bendahara Penerimaan, dan Bendahara Pengeluaran di seluruh Puskesmas di Kabupaten Siak dan Kabupaten Pelalawan. Hal ini dimaksudkan untuk dapat mengetahui tentang masalah mengenai pengaruh pemanfaatan teknologi informasi, kompetensi sumber daya manusia, dan pengawasan fungsional terhadap efektivitas pengelolaan keuangan Badan Layanan Umum Daerah (BLUD dengan Sistem Pengendalian Intern Pemerintah (SPIP) sebagai variabel moderasi yang diukur dengan menggunakan Skala Likert dengan 5 (lima) alternatif.

\section{Definisi Operasional Variabel dan Pengukuran Variabel}

\section{Efektivitas Pengelolaan Keuangan Badan Layanan Umum Daerah (BLUD)}

Efektivitas dalam Pengelolaan Keuangan merupakan penyelesaian seluruh kegiatan meliputi perencanaan dan penganggaran, pelaksanaan anggaran, pelaporan dan pertanggungjawaban serta pengawasan tepat pada waktunya dan di dalam batas anggaran yang telah tersedia, dan tercapainya tujuan atas sasaran yang telah direncanakan (Halim, 2004). Indikator efektivitas pengelolaan keuangan Badan Layanan Umum Daerah (BLUD) mengacu pada Permendagri No. 79 tahun 2018:
1. Perencanaan dan penganggaran
3. Pelaporan dan pertanggungjawaban
2. Pelaksanaan anggaran
4. Pengawasan

\section{Pemanfaatan Teknologi Informasi}

Pemanfaatan teknologi informasi adalah perilaku sikap individu dalam menggunakan teknologi informasi untuk menyelesaikan tugas dan meningkatkan kinerjanya. Pemanfaatan teknologi informasi diharapkan memberikan manfaat bagi pengguna sistem informasi dalam melaksanakan tugasnya atau perilaku dalam menggunakan teknologi pada saat melakukan pekerjaan. Pengukurannya berdasarkan intensitas pemanfaatan, frekuensi pemanfaatan dan jumlah aplikasi atau perangkat lunak yang digunakan (Wijana, 2017). Indikator pemanfaatan teknologi informasi di kembangkan oleh Tihay (2003):

1. Intensitas pemanfaatan

2. Frekuensi Pemanfaatan

3. Jumlah aplikasi atau perangkat lunak yang digunakan 


\section{Kompetensi Sumber Daya Manusia}

Kompetensi merupakan landasan dasar karakterisktik orang dan mengindikasikan cara berpikir, menyamakan situasi, dan mendukung untuk periode waktu cukup lama (Wibowo, 2016:272). Indikator kompetensi sumber daya manusia menurut Wibowo (2016):

1. Pendidikan

2. Pelatihan

3. Pengalaman

\section{Pengawasan Fungsional}

Sumarsono (2010:253) menyatakan bahwa pengawasan fungsional adalah pengawasan yang dilakukan oleh aparat pegawasan fungsional, baik yang berasal dari lingkungan internal pemerintah maupun yang berasal dari lingkungan eksternal pemerintah. Indikator untuk mengukur pengawasan fungsional mengacu pada Kepres RI No. 74 Tahun 2001 yaitu:

1. Pemeriksaan

2. Pengujian

3. Pengusutan

4. Penilaian

\section{Sistem Pengendalian Internal Pemerintah (SPIP)}

Menurut Peraturan Pemerintah Nomor 60 Tahun 2008 menyebutkan bahwa pengertian sistem pengendalian internal pemerintah adalah sebagai berikut: "proses yang integral pada tindakan dan kegiatan yang dilakukan secara terus menerus oleh pimpinan dan seluruh pegawai untuk memberikan keyakinan memadai atas tercapainya tujuan organisasi melalui kegiatan yang efektif dan efisien, keandalan pelaporan keuangan, pengamanan aset negara, dan ketaatan terhadap peraturan perundang-undangan”. Indikator SPIP mengacu pada PP No. 60 tahun 2008 diantaranya sebagai berikut:

1. Lingkungan pengendalian

2. Penilaian resiko

3. Kegiatan pengendalian

4. Informasi dan komunikasi

5. Pemantauan pengendalian intern 


\section{Metode Analisis Data}

Data dalam penelitian ini dianalisis menggunakan model Struktural Equation Modeling (SEM). Alasan penggunaan SEM yaitu SEM merupakan sekumpulan teknik statistikal yang memungkinkan pengujian sebuah rangkaian hubungan relatif rumit secara simultan. Menurut Hair dkk. (2006) mengenai sample yang representatif dengan menggunakan teknik analisis SEM adalah 100-200 responden.

Permodelan melalui SEM memungkinkan seorang peneliti dapat menjawab pertanyaan penelitian yang bersifat regresif maupun dimensional (Ferdinand, 2006). Analisis data dalam penelitian ini dilakukan peneliti dengan menggunakan pendekatan Partial Least Square (PLS).

\section{HASIL PENELITIAN DAN PEMBAHASAN}

\section{Hasil Statistik Deskriptif}

Stastistik deskriptif dimaksudkan untuk menganalisis data berdasarkan atas hasil yang diperoleh dari jawaban responden terhadap masing-masing indikator pengukur variabel. Statistik deskriptif terdiri dari mean, minimum, maximum, dan standar deviasi. Adapun analisis deskriptif variabel penelitian dapat dilihat pada tabel dibawah ini:

\section{Tabel 1}

\section{Hasil Statistik Deskriptif}

\begin{tabular}{lccccc}
\hline \multicolumn{1}{c}{ Variabel } & N & Min & Max & Mean & Std. Dev. \\
\hline Pemanfaatan Teknologi Informasi & 92 & 2 & 5 & 3.88199 & 0.72127 \\
Kompetensi Sumber Daya Manusi & 92 & 2 & 5 & 3.89855 & 0.72522 \\
Pengawasan Fungsional Fungsional & 92 & 2 & 5 & 4.12154 & 0.70574 \\
Efektivitas Pengelolaan Keuangan BLUD & 92 & 2 & 5 & 4.07261 & 0.7043 \\
Sistem Pengendalian Intern Pemerintah (SPIP) & 92 & 2 & 5 & 3.87609 & 0.67234 \\
\hline
\end{tabular}

\section{Sumber: Olah data dengan menggunakan SPSS}

\section{Uji Validitas dan Realibilitas}

Dalam penelitian ini, masing-masing konstruk (variabel) terdiri dari beberapa indikator pengukuran. Hasil output PLS menunjukkan nilai loading factor dari setiap konstruk berada di atas 0.5 dengan p-value $<0.05$. Hal ini menunjukkan bahwa indikator tersebut telah memenuhi convergent validity. Hasil output PLS menggambarkan bahwa akar kuadrat dari AVE (ditunjukkan di dalam tanda kurung) setiap konstruk lebih besar daripada nilai korelasi antara konstruk dengan konstruk lainnya, sehingga model mempunyai discriminant validity yang cukup sehingga telah memenuhi kriteria valid. Berdasarkan tabel diatas dapat disimpulkan bahwa masing-masing konstruk telah memenuhi kriteria reliabel. 


\section{Uji Evaluasi Model Struktural}

Hasil ouput PLS menujukkan bahwa R-squared untuk pengaruh variabel independen Pemanfaatan Teknologi Informasi (PTI), Kompetensi Sumber Daya Manusia (KSDM), Pengawasan Fungsional (PF) dan variabel moderasi Sistem Pengendalian Intern Pemerintah (SPIP) terhadap Efektivitas Pengelolaan Keuangan (EPK) adalah sebesar 0.518. Hasil ini menunjukkan bahwa 51.8\% variabel Efektivitas Pengelolaan Keuangan (EPK) dipengaruhi oleh variabel pemanfaatan teknologi informasi, kompetensi sumber daya manusia, pengawasan fungsional dan variabel moderasi sistem pengendalian intern pemerintah, sedangkan sisanya dipengaruhi oleh variabel lain.

\section{Hasil Uji Hipotesis}

Pengujian hipotesis dimaksudkan untuk membuktikan kebenaran dugaan penelitian atau hipotesis. Untuk melihat hasil uji hipotesis secara simultan atau secara bersama-sama dapat dilihat nilai path coefficients dan p-values dalam total effects hasil dari pengolahan data variabel secara simultan. Suatu hipotesis dapat diterima atau ditolak secara statistik dapat dihitung melalui tingkat signifikansinya. Tingkat signifikansi yang dipakai dalam penelitian ini adalah sebesar 5\%. Sehingga sebagai dasar pengambilan keputusan jika $p$-value $\leq 0.05$, maka hipotesis diterima, $p$-value $>0.05$, maka hipotesis ditolak.

Berikut ini dapat dilihat dari gambar berikut korelasi setiap variabel, yaitu gambar yang menyatakan pengaruh antara variabel pemanfaatan teknologi informasi, dan kompetensi sumber daya manusia.

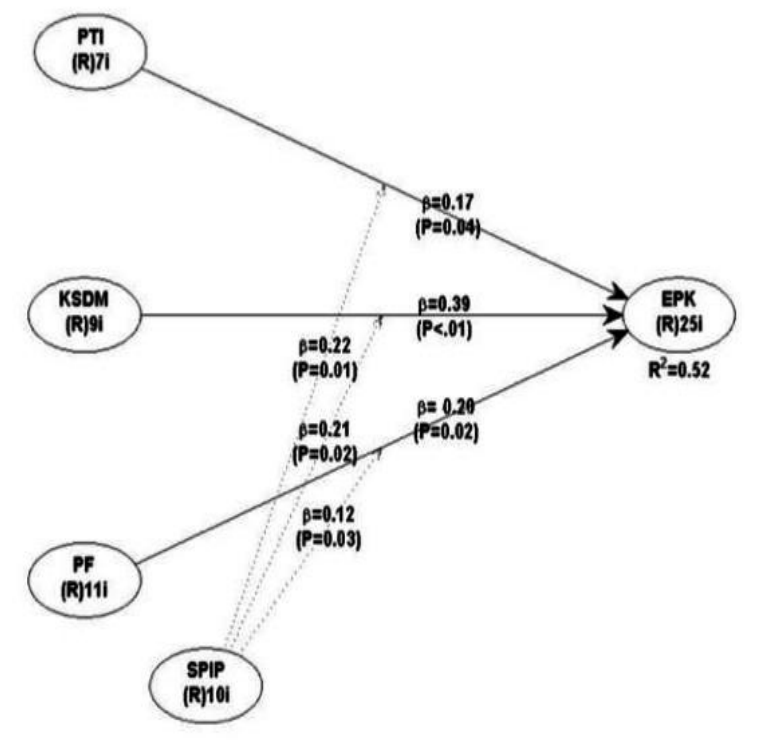

\section{Gambar 1}

\section{Output PLS}

Sumber: Olah data menggunakan WarPLS 
Tabel 2

Hasil Uji Hipotesis

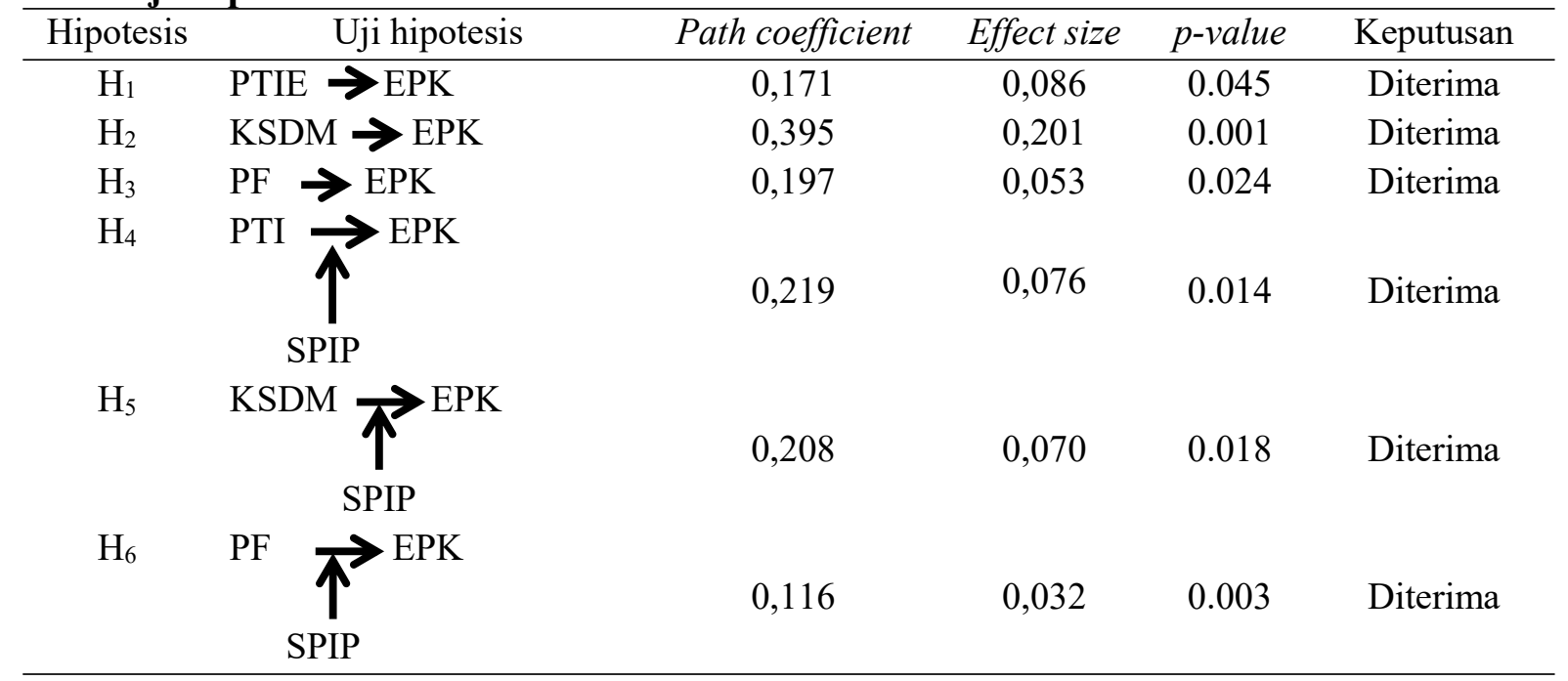

Sumber: Data Olahan WarpPLS (2020)

\section{Hasil Uji Hipotesis 1}

Berdasarkan gambar model struktural, dan dari tabel 2 dapat dilihat bahwa pengaruh dari variabel pemanfaatan teknologi informasi terhadap efektivitas pengelolaan keuangan Badan Layanan Umum daerah adalah sebesar 0.171. Koefisien regresi tersebut signifikan dengan nilai $\mathrm{p}$ (p-value) sebesar 0.045 atau lebih kecil dari 0.05. Sehingga, hipotesis 1 ini diterima. Dengan demikian dapat disimpulkan pemanfaatan teknologi informasi berpengaruh terhadap efektifitas pengelolaan keuangan Puskesmas BLUD.

Hasil analisis menunjukkan pemanfaatan teknologi yang tepat dapat meningkatkan efektivitas pengelolaan keuangan. Dengan memanfaatkan teknologi informasi baik individu maupun organisasi dalam menjalankan berbagai aktivitas dengan lebih efektif dan efisien, teknologi juga sebagai alat bantu pemerintah daerah yang digunakan untuk meningkatkan efektivitas impelementasi dari berbagai regulasi bidang pengelolaan keuangan daerah yang berdasarkan pada asas efisiensi, ekonomis, efektif, transparan, akuntabel dan auditabel sehingga dapat meningkatkan efektivitas pengelolaan keuangan Badan Layanan Umum daerah (djkd.kemendagri.go.id).

Hasil hipotesis ini mendukung teori stewardship di fokuskan pada harmonisasi antara principal dan steward dalam mencapai tujuan bersama yaitu tercapainya efektivitas dalam pengelolaan keuangan daerah. Adanya pemanfaatan teknologi informasi yang tepat akan meningkatkan efektivitas pengelolaan keuangan yang ada dan dengan demikian maka tujuan organisasi akan tercapai. Hal ini sejalan dengan hasil penelitian Komara dan Nila (2017) bahwa variabel pemanfaatan teknologi informasi berpengaruh terhadap efektivitas pengelolaan keuangan. 


\section{Hasil Uji Hipotesis 2}

Dari gambar model struktural, dan tabel 2 dapat dilihat bahwa pengaruh variabel kompetensi sumber daya manusia terhadap efektivitas pengelolaan keuangan Badan Layanan Umum daerah adalah sebesar 0.395. Koefisien regresi tersebut signifikan dengan nilai $\mathrm{p}$ ( $\mathrm{p}$ value) sebesar 0.001 atau lebih kecil dari 0.05, sehingga, hipotesis ini diterima. Dapat disimpulkan bahwa kompetensi sumber daya manusia berpengaruh terhadap efektifitas pengelolaan keuangan Badan Layanan Umum Daerah.

Diterimanya $\mathrm{H} 2$ menunjukkan bahwa sumber daya manusia yang berkompeten dapat meningkatkan efektivitas pengelolaan keuangan dimana dalam pencapaian efektivitas pengelolaan keuangan, pemerintah harus memiliki sumber daya manusia yang berkompeten. Sehingga dapat dikatakan bahwa semakin tinggi kompetensi sumber daya manusia maka kemungkinan akan terjadi peningkatan efektivitas pengelolaan keuangan dan sebaliknya jika kompetensi sumber daya manusia turun,maka efektivitas pengelolaan keuangan akan turun.

Adanya kompetensi sumber daya manusia memiliki kemampuan atau pengetahuan di bidang teknologi informasi serta memiliki keahlian teknis dan fungsional maka organisasi suatu pemerintah mampu mencapai keefektivitasan dalam pengelolaan keuangan daerah. Hal ini sejalan dengan penelitian Sari et al (2017) yang membuktikan bahwa kompetensi sumber daya manusia berpengaruh signifikan terhadap efektivitas pengelolaan keuangan daerah.

Kompetensi sumber daya manusia merupakan salah satu unsur penting dalam mengelola keuangan. Dimana dengan adanya sumber daya manusia yang berkompeten pada bidangnya yang memiliki kemampuan dan pengetahuan yang memadai maka sebuah instansi akan mampu mengelola keuangan dengan efektif. Di dalam pengelolaan keuangan daerah teori stewardship di fokuskan pada harmonisasi antara principal dan steward dalam mencapai tujuan bersama yaitu tercapainya efektivitas dalam pengelolaan keuangan daerah. Dengan memiliki sumber daya manusia yang berkompeten maka akan mampu meningkatkan efektivitas pengelolaan keuangan yang ada dan para principal akan merasa puas dengan instansi tersebut karna telah mampu melakukan pengelolaan keuangan secara efektif, Dengan demikian tujuan organisasi juga akan tercapai.

\section{Hasil Uji Hipotesis 3}

Dari gambar model struktural, dan dari tabel 2 dapat dilihat bahwa pengaruh dari variabel pengawasan fungsional terhadap efektivitas pengelolaan keuangan Badan Layanan Umum daerah adalah sebesar 0.197. Koefisien regresi tersebut signifikan dengan nilai $\mathrm{p}$ ( $\mathrm{p}$ value) sebesar 0.024 atau lebih kecil dari 0.05. Sehingga, hipotesis 3 ini diterima. Dapat 
disimpulkan bahwa pengawasan fungsional berpengaruh terhadap efektivitas pengelolaan keuangan Badan Layanan Umum Daerah.

Dari hasil pengujian hipotesis diatas yang menyatakan bahwa pengawasan fungsional berpengaruh terhadap efektivitas pengelolaan keuangan, hal ini juga dinyatakan oleh Halim (2004:312) bahwa dalam pelaksanaan pengelolaan keuangan daerah, pengawasan fungsional mutlak dilaksanakan sehingga keefektifan, keefisien dan keekonomisan yang dilaksanakan oleh pemerintah daerah dapat dicapai. Apabila pengawasan fungsional dilakukan oleh aparat pengawas fungsional dengan maksimal, maka efektivitas pengelolaan keuangan daerah akan tercapai. Terwujudnya pengelolaan keuangan yang efektif merupakan tujuan utama pemerintah daerah. Sehingga dengan dilaksanakannya pengawasan fungsional yang memadai akan menunjang pengelolaan keuangan yang efektif, efisien dan ekonomis.

Semakin baik pengawasan fungsional yang dilakukan oleh aparat pengawas fungsional maka pelaksanaan program kerja pemerintah akan semakin baik, hal ini akan mempengaruhi kefektivitasan dalam pengelolaan keuangan daerah. Pengawasan fungsional juga dapat meningkatkan keefektivitasan pengelolaan keuangan daerah, apabila semakin sering melakukan pengawasan maka semakin bagus pula efektivitas pengelolaan keuangan daerahnya. Hal ini sejalan dengan penelitian yang dilakukan oleh Jhoni Iskandar (2015) bahwa pengawasan fungsional berpengaruh terhadap efektivitas pengelolaan keuangan daerah.

Dengan pengawasan fungsional yang dilakukan akan meningkatkan efektivitas pengelolaan keuangan, karena pengawasan yang dilakukan akan mampu menilai pelaksanaan program-program yang akan direncanakan salah satunya dalam hal mengelola keuangan. Di dalam teori stewardship efektivitas pengelolaan keuangan daerah merujuk pada keharmonisan hubungan antara steward dan principal dalam mencapain tujuan bersama yang mana tujuan nya adalah tercapainya efektivitas pengelolaan keuangan. Semakin sering melakukan pengawasan fungsional dengan baik akan meningkatkan efektivitas pengelolaan keuangan, yang artinya aparat pengawas akan melaksanakan pengawasan dengan baik agar tercapainya efektivitas pengelolaan keuangan dan tercapai pula tujuan organisasi tersebut.

\section{Hasil Uji Hipotesis 4}

Dari gambar model struktural, dan dari tabel 2 dapat dilihat bahwa sistem pengendalian intern pemerintah dapat memoderasi pengaruh dari pemanfaatan teknologi informasi terhadap efektivitas pengelolaan keuangan Badan Layanan Umum Daerah dengan koefisien regresi sebesar 0.219. Koefisien regresi tersebut signifikan dengan nilai $\mathrm{p}$ ( $\mathrm{p}$-value) sebesar 0.024 atau lebih kecil dari 0.05. Sehingga, hipotesis ini diterima. Dapat disimpulkan 
bahwa sistem pengendalian intern pemerintah dapat memoderasi pengaruh pemanfaatan teknologi informasi terhadap efektivitas Badan Layanan Umum Daerah.

Dengan adanya sistem pengendalian intern pemerintah dapat mempengaruhi tatacara mereka bekerja dimana sistem pengendalian intern pemerintah dapat memoderasi hubungan pemanfaatan teknologi informasi terhadap efektivitas pengelolaan keuangan. Apabila sistem pengendalian intern di organisasi baik maka pegawai melakukan tugasnya dengan mamanfaatkan teknologi informasi yang ada dengan sistem yang telah diterapkan oleh organisasi tersebut. Sebaliknya, apabila sistem pengendalian intern pemerintah yang ada di dalam organisasi tersebut tidak berjalan dengan baik maka dapat memperlemah hubungan antara pemanfaatan terknologi informasi terhadap efektivitas pengelolaan keuangan. Dengan kata lain, sistem pengendalian intern ini dapat memoderasi pengaruh pemanfaatan teknologi informasi terhadap efektivitas pengelolaan keuangan. Hal ini sejalan dengan penelitian yang telah dillakukan sebelumnya oleh Desilia Tanzerina (2017) bahwa sistem pengendalian intern pemerintah dapat memoderasi pengaruh variabel independen terhadap efektivitas pengelolaan keuangan daerah.

Pemanfaatan teknologi informasi dan sistem pengendalian intern pemerintah merupakan hal penting di dalam organisasi demi tercapainya tujuan organisasi dalam mengelola keuangan. Di dalam pengelolaan keuangan daerah teori stewardship di fokuskan pada harmonisasi antara principal dan steward dalam mencapai tujuan bersama yaitu tercapainya efektivitas dalam pengelolaan keuangan daerah. Dengan pemanfaatan teknologi informasi yang tepat akan meningkatkan efektivitas pengelolaan keuangan yang ada. Apabila pemanfaatan teknologi tersebut dimanfaatkan dengan baik maka pengelolaan keuangan akan efektif, dan akan menjadi lebih efektif apabila sistem pengendalian intern pemerintah di suatu organisasi tersebut berjalan sesuai dengan memenuhi unsur-unsur sistem pengendalian intern pemerintah tersebut. Principal akan merasa puas karena pengelolaan keuangan telah efektif dengan demikian maka tujuan organisasi akan tercapai secara maksimal.

\section{Hasil Uji Hipotesis 5}

Hasil uji t menunjukkan p value sebesar $0.018<0.05$ yang berarti hipotesis 5 diterima. Nilai path koefisien positif senilai 0,208. Dari pengujian hipotesis di atas menyatakan bahwa sistem pengendalian intern pemerintah dapat memoderasi pengaruh dari kompetensi sumber daya manusia terhadap efektivitas pengelolaan keuangan Badan Layanan Umum Daerah (BLUD).

Unsur penting dalam mengelola keuangan daerah yaitu kompetensi sumber daya 
manusia dan sistem pengendalian intern pemerintah karena dinilai dapat meningkatkan efektivitas pengelolaan keuangan. Dimana dengan adanya sumber daya manusia yang berkompeten pada bidangnya yang memiliki kemampuan dan pengetahuan yang memadai maka sebuah instansi akan mampu mengelola keuangan dengan efektif. Apabila ditambahkan sistem pengendalian intern pemerintah maka hubungan antara keduanya akan menjadi lebih kuat atau lebih lemah, sesuai dengan impelementasi sistem pengendalian intern pemerintah yang ada di suatu organisasi. Di dalam pengelolaan keuangan daerah teori stewardship di fokuskan pada harmonisasi antara principal dan steward dalam mencapai tujuan bersama yaitu tercapainya efektivitas dalam pengelolaan keuangan daerah. Dengan memiliki sumber daya manusia yang berkompeten maka akan mampu meningkatkan efektivitas pengelolaan keuangan yang ada dan sistem pengendalian intern pemerintah disini berperan penting untuk memperkuat atau memperlemah hubungan antara keduanya dengan tujuan peningkatan efektivitas pengelolaan keuangan dan para principal akan merasa puas karna telah mampu melakukan pengelolaan keuangan secara efektif dan dengan demikian tujuan organisasi juga akan tercapai.

\section{Hasil Uji Hipoteis 6}

Hasil uji t menunjukkan p value sebesar $0.003<0.05$ yang berarti hipotesis 5 diterima. Nilai path koefisien positif senilai 0,116. Dapat disimpulkan bahwa hipotesis 6 dapat diterima. Sistem pengendalian intern pemerintah memperkuat hubungan antara pengawasan fungsional dengan efektivitas pengelolaan keuangan. karena sistem pengendalian intern pemerintah akan menjadi tolak ukur dalam efektivitas pengelolaan keuangan sehingga pengelolaan keuangan akan efektif. Untuk pengawasan fungsional dilakukan, agar terarah pengelolaan keuangan ke arah yang lebih baik sehingga efektivitas pun tercapai. Apabila pengawasan fungsional dilakukan dan mengacu pada sistem pengendalian intern pemerintahan maka semakin baik pula pencapaian efektivitas pengelolaan keuangannya. Sebaliknya, apabila sistem pengendalian intern pemerintah yang ada tidak berjalan dengan semestinya maka akan pengelolaan keuangan yang ada menjadi tidak efektif. Hal ini sejalan dengan penelitian yang telah dillakukan sebelumnya oleh Tanzerina (2017) bahwa sistem pengendalian intern pemerintah dapat memoderasi pengaruh variabel independen terhadap efektivitas pengelolaan keuangan daerah.

Dengan pengawasan fungsional yang dilakukan akan meningkatkan efektivitas pengelolaan keuangan, karena pengawasan yang dilakukan akan mampu menilai pelaksanaan program-program yang akan direncanakan salah satunya dalam hal mengelola keuangan. 
Apabila ditambahkan sistem pengendalian intern pemerintah maka hubungan antara keduanya akan menjadi lebih kuat atau lebih lemah. Di dalam teori stewardship efektivitas pengelolaan keuangan daerah merujuk pada keharmonisan hubungan antara steward dan principal dalam mencapain tujuan bersama yang mana tujuan nya adalah tercapainya efektivitas pengelolaan keuangan. Semakin sering melakukan pengawasan fungsional dengan baik akan meningkatkan efektivitas pengelolaan keuangan. Dengan sistem pengendalian intern pemerintah yang baik maka akan lebih meningkatkan efektivitas pengelolaan keuangan, sebaliknya jika sistem pengendalian intern pemerintah tidak berjalan dengan baik maka pengelolaan keuangan tidak akan efektif yang artinya aparat pengawas akan melaksanakan pengawasan dengan baik agar tercapainya efektivitas pengelolaan keuangan dan dengan ditambahkan sistem pengendalian intern pemerintah maka pencapaian efektivitas pengelolaan keuangan akan lebih meningkat tetapi jika sistem pengendalian intern pemerintah tersebut tidak berjalan dengan baik maka dapat menurunkan tingkat pencapaian efektivitas pengelolaan keuangan. Dengan meningkatnya efektivitas pengelolaan keuangan, dapat tercapai pula tujuan organisasi secara maksimal.

\section{SIMPULAN}

Dari hasil penelitian ini dapat disimpulkan bahwa pemanfaatan tekhnologi informasi, kompetensi sumber daya manusia, dan pengawasan fungsional terhadap efektivitas pengelolaan keuangan Badan Layanan Umum daerah. Sistem pengendalian internal dapat memoderasi hubungan pemanfaatan tekhnologi informasi, kompetensi sumber daya manusia, dan pengawasan fungsional terhadap efektivitas pengelolaan keuangan Badan Layanan Umum daerah. Keterbatasan dalam penelitian ini adalah Penelitian ini hanya dilakukan pada Puskesmas, sedangkan Badan Layanan Umum Daerah (BLUD) di suatu daerah bukan hanya Puskesmas. Penelitian ini hanya ditujukan kepada empat responden yaitu Kepala Puskesmas, Kepala Tata Usaha, Bendahara Penerimaan dan Bendahara Pengeluaran pada Puskesmas di Kabupaten Siak dan Kabupaten Pelalawan. Atau pihak yang ditunjuk oleh Kepala Puskesmas, sehingga hasilnya belum dapat digeneralisasikan. Penelitian ini hanya menggunakan variabel pemanfaatan teknologi informasi, kompetensi sumber daya manusia, pengawasan fungsional, sistem pengendalian intern pemerintah dan efektivitas pengelolaan keuangan. Sementara itu, masih banyak variabel lain yang memungkinkan berpengaruh terhadap efektivitas pengelolaan keuangan.

Dengan memperhatikan kesimpulan penelitian dan keterbatasan dalam penelitian diatas, penulis memberikan beberapa saran, antara lain: penelitian selanjutnya diharapkan 
meneliti di seluruh Badan Layanan Umum Daerah (BLUD) yang ada di daerah yang ingin di teliti tersebut. Penelitian selanjutnya diharapkan menambahkan responden dengan memilih responden yang benar-benar bertanggungjawab langsung atas pengelolaan keuangan atau menambah responden lain yang bertanggungjawab dan mengetahui efektif atau tidaknya pengelolaan keuangan yang ada di Puskesmas tersebut serta menggunakan lokasi yang berbeda agar hasil penelitian dapat dibandingkan dengan penelitian sebelumnya. Penelitian selanjutnya sebaiknya menambah variabel independen lain yang tidak dijelaskan dalam penelitian ini, Peneliti selanjutnya diharapkan untuk mengembangkan penelitian ini dengan menambah variabel lain yang bisa mempengaruhi efektivitas pengelolaan keuangan.

\section{REFERENSI}

Ashari, I., Aslang, A., Yahya, Z., \& Sukur. (2019). Efektifitas Pengelolaan Badan Layanan Umum (BLU). Diklat Politeknik Ilmu Pelayaran Kota Makassar. Jurnal Karya Imiah Venus. Vol 7 No 13.

Bulan, S.G.I., Tinangon, J., \& Mawikere, L. (2017). Pengaruh Kualitas Pengelola Keuangan dan Sistem Pengendalian Intern Pemerintah (SPIP) Terhadap Efektivitas Pengelolaan Keuangan Daerah Pada Inspektorat Pemerintah Kota Manado. Jurnal Riset Akuntansi Going Concern. Vol. 12, No. 1. Fakultas Ekonomi dan Bisnis, Universitas Sam Ratulangi, Manado.

Halim. A (2004). Akuntansi Keuangan Daerah. Penerbit Salemba Empat. Jakarta.

Iskandar, J. (2015). Pengaruh Sistem Pengendalian Intern Pemerintah, Kompetensi Sumber Daya Manusia dan Pengawasan Fungsional Terhadap Efektivitas Pengelolaan Keuangan Daerah (Studi Empiris Pada Satuan Kerja Perangkat Daerah Kota Pekanbaru). JOM FEKON. Vol. 2, No. 2.

Lidyawati, L. (2019). Analisis Layanan Keuangan Dalam Penilaian Kinerja Keuangan Badan Layanan Umum Daerah Kota Bekasi. Goodwil: Jurnal Penelitian Akuntansi.

Lisdiani. (2015). Penelitian Pengaruh Pengawasan Fungsional Terhadap Efektivitas Pengelolaan Keuangan Daerah Pada Pemerintah Kota Tasikmalaya.

Mardiasmo. (2007). Edisi Revisi Perpajakan. Yogyakarta: Andi.

Utami, N. (2016). Pengaruh Sistem Pengendalian Intern Pemerintah, Kinerja Pegawai, Pengawasan Melekat dan Pengawasan Fungsional Terhadap Efektivitas Pengelolaan Keuangan Daerah (Studi Pada SKPD Kabupaten Lima Puluh Kota Payakumbuh Sumatra Barat). JOM Fekon. Vol. 3 No. 1.

Sekretariat Negara RI. (2005). Peraturan Pemerintah No. 23 Tahun 2005 Tentang Pengelolaan Keuangan Daerah. 
Priastuti, W.Y., \& Masdjojo, G.N. (2017). Efektivitas Kinerja Keuangan dan Non Keuangan Pada Pola Pengelolaan Keuangan Badan Layanan Umum Daerah (PPK BLUD) RSUD Ambarawa Kabupaten Semarang. Prosiding Multi Disiplin.

Saleba \& Nurjannah, S. (2014). Pengaruh Sistem Pengendalian Intern Pemerintah dan Kompetensi Sumber Daya Manusia Terhadap Efektivitas Pengelolaan Keuangan Daerah (Studi Pada 6 Dinas Di Kabupaten Baubau, Makasar). Skripsi. Universitas Hasanuddin.

Sari, D.B.M., Wiyanti, A. \& Masitoh, E. (2017). Pengaruh Sistem Pengendalian Intern Pemerintah dan Kompetensi Sumber Daya Manusia Terhadap Efektivitas Pengelolaan Keuangan Daerah. djkd.kemendagri.go.id.

Sukarta, I.W., Badera, D.M., \& Ratnadi, N.M.D. (2017). Pengaruh Kompetensi, Pemanfaatan Teknologi Informasi, Komitmen dan Revisi Anggaran Pada Efektivitas Pengelolaan Anggaran Universitas Udayana. E-Jurnal Ekonomi dan Bisnis Universitas Udayana 6.11: 3917-3950.

Tanzerina, D. (2015). Pengaruh Kompetensi Sumber Daya Manusia (SDM) dan Sistem Akuntansi Keuangan Daerah (SAKD) Terhadap Efektivitas Pengelolaan Keuangan Daerah dengan Pengaruh Sistem Pengendalian Intern Pemerintah Sebagai Variabel Moderating (Studi Empiris Pada Satuan Kerja Perangkat Daerah Kabupaten Indragiri Hulu Provinsi Riau Tahun 2015). JOM Fekon. Vol. 4.No. 1. 